\title{
Biodegradation of Sulphide in Biogas by Biofilm on Salak Fruit Seeds: Accuracy of Quasi-steady-state Approximation
}

\author{
Retno A. S. Lestari ${ }^{*}$, Wahyudi B. Sediawan ${ }^{2}$, and Sarto $^{2}$ \\ ${ }^{1}$ Chemical Engineering Department, 17 Agustus 1945 University, Semarang, Indonesia \\ ${ }^{2}$ Chemical Engineering Department, Gadjah Mada University, 2 Yogyakarta 55281, Indonesia
}

\begin{abstract}
This study tried to explore the quantitative description of removal of hydroden sulphide $\left(\mathrm{H}_{2} \mathrm{~S}\right)$ by bio-filtration. $\mathrm{H}_{2} \mathrm{~S}$ is degraded by bacteria immobilized on the packing materials of Salak fruit seeds inside a column. Two kinetics models are proposed. In both models, the biofilm formed on the packing material is assumed to be thin, so intra-film gradient of $\mathrm{H}_{2} \mathrm{~S}$ concentration can be neglected. In model 1 , material balances of $\mathrm{H}_{2} \mathrm{~S}$ in the bio-film as well as in the flowing gas are set-up. The growth of the bio-film is modelled by Monod's equation. A set of three simultaneous partial differential equations are obtained. Model 2 is set-up using the same concepts as in model1, but the gas phase is assumed to be quasi-steady-state. This assumption reduces the partial differential equation in model 1 to be an ordinary differential equation which is easier to be solved. The comparisons of the results of model 1 and model 2 can be applied to justify the applications of quasi-steady-state approximation. It turned out that the differences of calculated $\mathrm{H}_{2} \mathrm{~S}$ concentration results are approximately small, around $6 \mathrm{ppm}$. Hence, it can be concluded that quasi-steady-state approximation in the gas phase is suggested to be applied.
\end{abstract}

\section{Introduction}

Biogas, a potential biomass-based material for alternative energy, is produced by anaerobic decomposition of organic substances such as agricultural waste, animal waste, household waste, waste water, and household waste [1]. Biogas is a side product of biological activity to produce energy by converting organic materials in anaerobic condition. The process is commonly recognized as fermentation. This process actually consists of three major steps, which are hydrolysis, asidogenesis and methanogenesis [2]. The compositions of biogas are typically methane $\left(\mathrm{CH}_{4}\right) 55$ $70 \%$, carbon dioxide $\left(\mathrm{CO}_{2}\right) \quad 30-45 \%$ and hydrogen sulphide $\left(\mathrm{H}_{2} \mathrm{~S}\right) 0-1.5 \%$ [3]. According to Pipatmanomai et al. [4] even though the sulphide compounds contained in biogas are relatively small, they can corrode the materials of equipment utilizing biogas.

Hydrogen sulphide removal from biogas can be achieved by physical and chemical processes such as scrubbing [5], absorption [6], [7], adsorption [8] and reactive absorption. Physical and chemical processes are commonly need high cost and generate other waste.

An alternative method to reduce sulphide compounds in biogas is biochemical process, especially bio-filtration [9]. This process uses a bio-filter containing sulphide degrading bacteria immobilize on the surface of packing material [10].
Bio-filtration is a relatively simple process. Gas containing $\mathrm{H}_{2} \mathrm{~S}$ was flowed through a pile of packing material which has a surface coated by pollutantdegrading bacteria as a biofilm [11]. In this bio-filtration system, $\mathrm{H}_{2} \mathrm{~S}$ is absorbed by the biofilm, and then degraded by microorganism to produce elemental sulphur (if oxygen was limited) and $\mathrm{SO}^{-2}$ (if oxygen is in excess), which are non-corrosive [12].

Biofilms are microorganisms that attached and stick together in a polymer matrix [13]. The attachment of microorganisms on the surface of the packing material is very important for the initiation of the development of biofilm [14]. Sulphide-oxidizing bacteria include: bacteria of the genus Thiobacillus (kemoautotrof) litotrof), green and purple sulphur bacteria (photoautotrophs), and types of heterotrophic include Atrhrobacter, Bacillus, Mikrococcus, Mycobacterium and Pseudomonas [15].

The packing material can be either organic or inorganic compounds. In selecting the packing materials for bio-filter there are several criteria that must be fulfilled include nutrient content (source of $\mathrm{C}$ and $\mathrm{N}$ ), moisture content, $\mathrm{pH}$, porosity, ability to absorb contaminants, lightweight, and cheap $[12,16]$.

This research used salak fruit seeds (SFS) for biofilter packing, because SFS easily absorbs water, has a nearly uniform size, containing nutrition and is relatively

\footnotetext{
* Corresponding author: retnotengaran $@$ gmail.com
} 
rigid. Furthermore, it is largely available and low cost [17]. The utilized sulphide degrading bacteria are isolated from local area, specifically Srandakan, Bantul, Yogyakarta.

Even though a number of studies on sulphide gas removal with bio-filters has been extensively conducted, the use of salak fruit seeds as packing material has never be done. Studies on the removal of $\mathrm{H}_{2} \mathrm{~S}$ in biogas commonly used a bio-filter with other packing materials and mostly focused on semi quantitative descriptive aspects, namely removal efficiency of $\mathrm{H}_{2} \mathrm{~S}$ gas (RE). Although there was a number of researcher studied quantitative description, their approaches are still open for improvement.

This study aims to develop a kinetic model that can be applied to design a large scale bio-filter for sulphide elimination from biogas. Special focus in this study is to explore the tolerability of quasi-steady-state approximation for the gas flowing through the column.

This work is a quantitative descriptive study; applying the fundamental concepts of mass transfer and kinetics of biochemical reactions of sulphide compounds in the packed bed. The study included laboratory experiments to generated data for verifications of the kinetic models proposed.

\section{Mathematical models}

Previous researchers who have done modelling in the process of gas and liquid waste handling using bio-filters include Spigno et al. [18] in the elimination of phenol, Majumder et al. [19] in the process of removal of divalent copper dissolved in water, Jaber et al. [20] in modelling bio-filters for hydrogen sulphide contained in the air, Meena et al. [21] makes the mathematical modelling of the separation of a mixture of hydrophilic (methanol) and hydrophobic ( $\alpha$-Pirene), Santos et al. [22] used a mathematical model for the removal of hydrogen sulphide by oxidation in the bio-filter, Kim and Deshusses [23] calculate the mass transfer coefficient on the packing material used for bio-filter, either in the gas layer or the liquid layer. Furthermore Yang et al. [24] makes modelling of porosity variations of bio-filter equipment used in rotary drum, Ramirez et al. [25] studied the kinetics of microbial growth and biodegradation of methanol and toluene, De Visscher and $\mathrm{Li}$ [26] studied the disappearances modelling toluene contained in the air, Agarwal et al. [27] studied the mass balance for phenol degradation events. Modelling in this study was set-up by adopting and combining the basic ideas that emerged in the previous studies.

The mathematical modelling of sulphide removal process with bio-filter columns proposed was based on the most fundamental concepts of mass transfer, phase equilibrium and kinetics of chemical reactions, and tried to avoid the use of special empirical equations. The solution of the mathematical equations formed is also based on common numerical methods, and avoiding special simplification. Two models were proposed with the objective to explore the tolerability of quasi-steady- state approximation for the gas flowing through the column

\subsection{Model 1}

Assuming that biofilms are relatively thin, model 1 consider that the sulphide concentration in the biofilm at certain axial column position is uniform and the value is equal to the sulphide concentration at the surface of biofilm $(\mathrm{Cs}=\mathrm{Csi})$. Furthermore the sulphide concentration in the biogas flowing in the column is considered to be unsteady-state.

Similar to Lestari [28], in the model development, the following simplifications are also applied:

1. The gas phase is plug-flow with no axial dispersions.

2. The biofilm is formed on the surface of the SFS only.

3. The thickness of the biofilm is relatively small compared to size of the SFS, so the geometry of the biofilm can be assumed as a slab.

4. Biodegradation reaction occurs in the biofilm only, and follows Monod's type equation.

5. The biofilm thickness increases as time progresses.

6. The system is isothermal.

Sulphide material balance in the biofilm is as follows:

(The rate of accumulation of sulphide in the biofilm) = (The rate of sulphide mass transfer from the gas to the biofilm) - (The rate of biodegradation in the biofilm)

$$
\frac{\partial C_{S}}{\partial t}=\frac{k_{C}}{\delta}\left(C_{G}-C_{G i}\right)-r_{A}
$$

The gas-biofilm phase equilibrium of sulphide follows Henry's type equation:

$$
C_{G i}=H_{S} * C_{S}
$$

The rate of biodegradation is approximated by Monod's equation:

$$
r_{A}=\frac{\mu_{\max } C_{s}}{C_{s}+K_{S}}
$$

The thickness increase of the biofilm is caused by the growth of microbes, so it is obtained that:

$$
\frac{d \delta}{d t}=\frac{\frac{Y_{X}}{S}}{\rho} \cdot r_{A \cdot} \cdot \delta
$$

Since the axial dispersion is to be neglected, material balance of the sulphide in the gas can be set-up as follows:

$$
\frac{\partial C_{G}}{\partial t}=-\frac{G}{\varepsilon S} \frac{\partial C_{G}}{\partial z}-\frac{k_{C} a_{S}}{\varepsilon}\left(C_{G}-C_{G i}\right)
$$

The finite difference approximation (FDA) of equation (1) is as follows:

$$
\left(C_{S}\right)_{j+1}=\left(C_{S}\right)_{j}+\frac{k_{C} \Delta t}{\delta}\left(\left(C_{G}\right)_{j}-H_{S}\left(C_{S}\right)_{j}\right)-\left(r_{A}\right)_{j}
$$

Then, FDA for equation (4) produces:

$$
\delta_{j+1}=\delta_{j}+\frac{Y_{X / S}}{\rho} r_{A} \delta_{j} \Delta t
$$

Equation (5) is then approximated by: 


$$
\begin{aligned}
\left(C_{G}\right)_{i, j+1}= & \left(C_{G}\right)_{i, j}-\frac{G}{\varepsilon \cdot S} \frac{\Delta t}{\Delta z} \frac{\left(C_{G}\right)_{i+1, j}-\left(C_{G}\right)_{i-1, j}}{2 \Delta z} \\
& -\frac{k_{C} a}{\varepsilon} \Delta t\left(\left(C_{G}\right)_{i, j}-H_{S}\left(C_{S}\right)_{i, j}\right)
\end{aligned}
$$

\subsection{Model 2}

Model 2 is basically similar to model 1 , but quasisteady-state a simplification for the gas phase is applied. Hence equation (1), (2), (3), (4), (6), (7) and (8) are the same, but equation (5) can be simplified since the term $d C_{g}$ vanishes and the result is:

$$
\frac{\partial C_{G}}{\partial z}=-\frac{k_{C} a S}{G}\left(C_{G}-C_{G i}\right)
$$

The FDA for equation (9) is as follows:

$$
\left(C_{G}\right)_{i+1, j}=\frac{\left(C_{G}\right)_{i, j}+\gamma \cdot H_{S} \cdot \Delta z \cdot\left(C_{S}\right)_{i+1, j}}{(1+\gamma \Delta z)}
$$

where $\gamma=\frac{k_{C} a}{G}$.

Mas transfer coeficient of sulphide in the gas film is then appriximated by the equation of:

$$
k_{G}=a_{0} G^{a_{1}}
$$

in which $\mathrm{a}_{0}$ and $\mathrm{a}_{1}$ are constants.

\section{Research Methodology}

\subsection{Experimental Data}

The experimental data applied to test the accuracies of the mathematical models are from Lestari [29].

\subsection{Computation}

The FDA for model 1 and 2 are solved using Fortran programs. It turned out that the calculation time for each experimental run using model 1 is approximately 1 minute. Meanwhile the one using model 2 is approximately 3 minute. This comparison shows that significant saving of time is observed.

\section{Results and discussions}

Simulations applying the two mathematical models proposed were performed using adjustable values of parameters involved until the results are close to the experimental data obtained. The comparison between the calculated results and the experimental data for the models are shown in Table 4.1, Table 4.2, as well as in Fig 4.5 and Fig 4.6. It can be observed that the calculation results using the two models are both close to the experimental data. It means that the two mathematical models proposed are adequate to quantitatively describe $\mathrm{H}_{2} \mathrm{~S}$ removal from biogas using biofilm on packed bed of SFS.

Table 4.1. Comparison of The results of model 1 and model 2 to experimental data (Debit $500 \mathrm{~mL} / \mathrm{hr}$ )

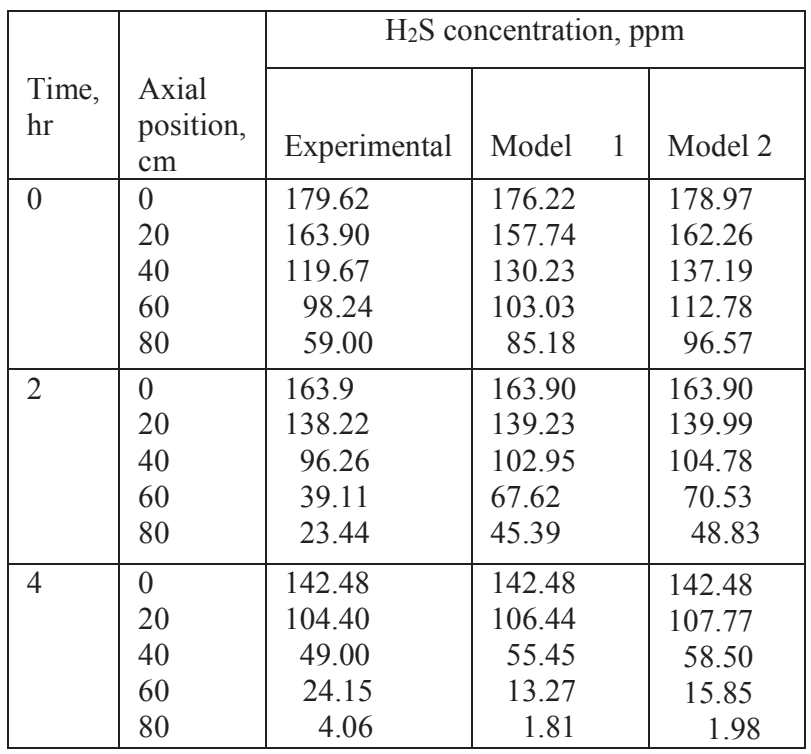

Table 4.2. Comparison of The results of model 1 and model 2 to experimental data (Debit $800 \mathrm{~mL} / \mathrm{hr}$ )

\begin{tabular}{|l|l|l|l|l|}
\hline \multirow{4}{*}{$\begin{array}{l}\text { Time, } \\
\text { h }\end{array}$} & \multirow{2}{*}{$\begin{array}{l}\text { Axial } \\
\text { position, } \\
\end{array}$} & \multicolumn{3}{|c|}{$\mathrm{H}_{2}$ S concentration, ppm } \\
\cline { 3 - 5 } & cm & Experimental & Model 1 & Model 2 \\
\hline 0 & 0 & 87.85 & 88.02 & 88.02 \\
& 20 & 82.69 & 78.24 & 78.13 \\
& 40 & 75.60 & 63.81 & 63.17 \\
& 60 & 53.01 & 49.70 & 48.91 \\
& 80 & 41.49 & 40.60 & 39.62 \\
\hline 2 & 0 & 89.99 & 90 & 90.00 \\
& 20 & 73.31 & 76.24 & 75.81 \\
& 40 & 56.96 & 56.30 & 55.29 \\
& 60 & 37.89 & 37.36 & 35.90 \\
& 80 & 15.49 & 25.86 & 24.19 \\
\hline 4 & 0 & 89.51 & 89.51 & 89.51 \\
& 20 & 60.98 & 70.02 & 69.23 \\
& 40 & 45.92 & 42.64 & 40.92 \\
& 60 & 22.17 & 18.85 & 16.60 \\
& 80 & 5.06 & 7.79 & 5.80 \\
\hline
\end{tabular}

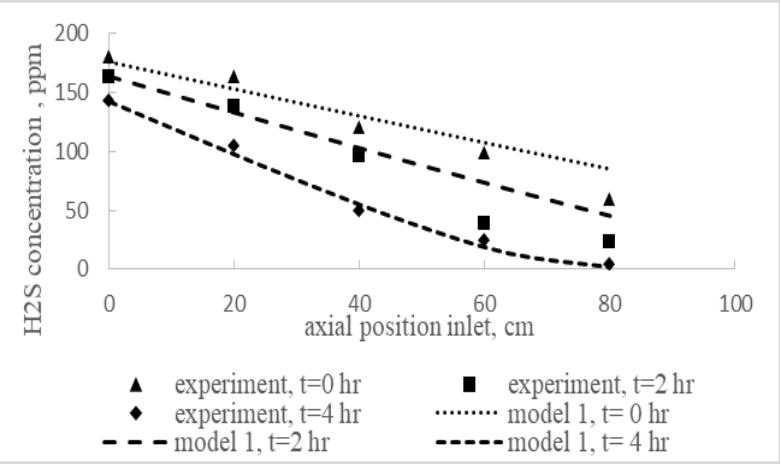

Fig 4.1 $\mathrm{H}_{2} \mathrm{~S}$ concentration versus axial position at various time at the debit of $500 \mathrm{~mL} / \mathrm{h}$ for experimental data and model 1 


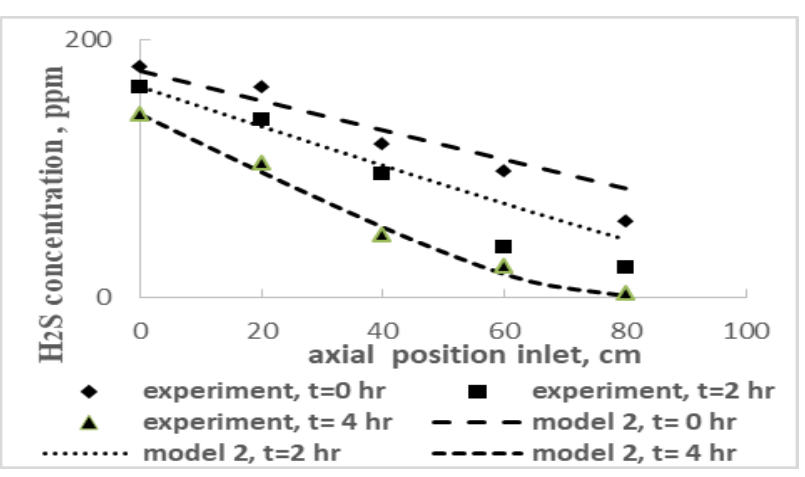

Fig 4.2 $\mathrm{H}_{2} \mathrm{~S}$ concentration versus axial position at various time at the debit of $500 \mathrm{~mL} / \mathrm{h}$ for experimental data and model 2

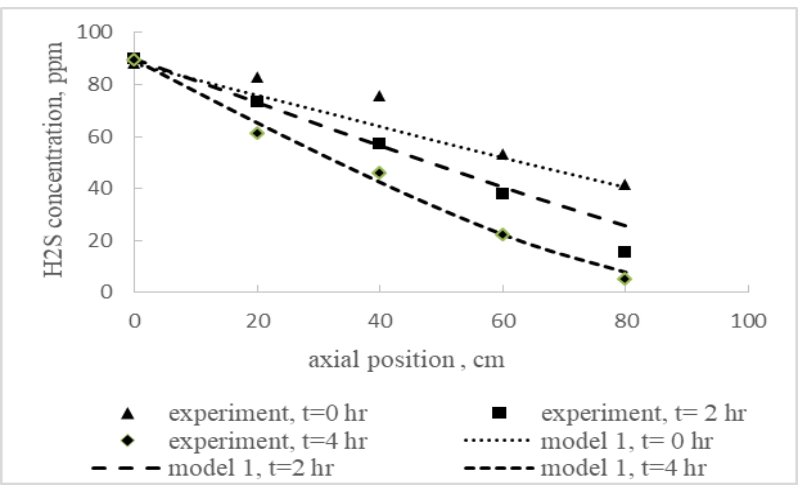

Fig 4.3 $\mathrm{H}_{2} \mathrm{~S}$ concentration versus axial position at various time at the debit of $800 \mathrm{~mL} / \mathrm{h}$ for experimental data and model 1

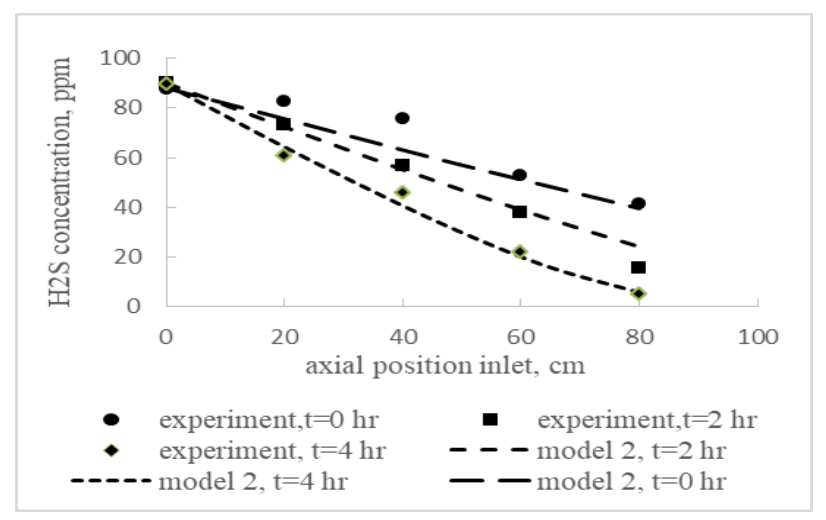

Fig $4.4 \mathrm{H}_{2} \mathrm{~S}$ concentration versus axial position at various time at the debit of $800 \mathrm{~mL} / \mathrm{h}$ for experimental data and model 2

It can also be observed in Table 4.1,Fig 4.1, Fig 4.2 and Table 4.2, Fig 4.3, Fig 4.4 that the results by model 1 are slightly better than the ones of model 2 , even though the differences are relatively small. Since the difference between model 1 and model 2 is in the assumption of quasi-steady-state, it can be concluded that simplification of quasi- steady-state in the gas phase gives only minor effects. This phenomenon is logical since the hold-up time of the gas inside the column is relatively very small compare to the time of process. The hold-up time of the process is approximately 0.054 hours, meanwhile time of process approximately 2 hours.

The average absolute errors of model 1 and model 2 are comparable, approximately $6 \mathrm{ppm}$. All in all, this comparison shows that both models have almost the same accuracies. Model 1 is only slightly better than model 2. Hence quasi-steady-state approximation in the gas phase can be applied with only small deviation.

For model 1 and model 2, the adjustable parameters applied were: the maximum specific growth rate of bacteria $\left(\mu_{\max }\right)=9.3 \mathrm{E}-7 \mathrm{~s}^{-1}, \mathrm{~K}_{\mathrm{S}}=4.0 \mathrm{E}-7 \mathrm{~g} \mathrm{~cm}^{-3}, \mathrm{H}_{\mathrm{S}}=0.7$, $\mathrm{Y}_{\mathrm{X} / \mathrm{S}}=60$, and the constants in mass transfer coefficient equation $\mathrm{a}_{0}=0.038$ and $\mathrm{a}_{1}=0.25$.

\section{Conclusion}

Based on the results of this study it can be concluded that:

1. The accuracies of mathematical models proposed (model 1 and model 2) are turned out to be comparable since the average absolute errors for both models are approximately 6 ppm.

2. Quasi-steady-state approximation in the gas phase gives only minor deviation in biodegradation of sulphide in biogas by biofilm on salak fruit seeds.

3 . The computing times for model 1 is approximately 3 times of the one of model 2. Since the accuracies are similar, it is suggested the use of model 2.

4. For model 1 and model 2, the adjustable parameters applied were: the maximum specific growth rate of bacteria $\left(\mu_{\max }\right)=9.3 \mathrm{E}-7 \mathrm{~s}^{-1}, \mathrm{~K}_{\mathrm{S}}=4.0 \mathrm{E}-7 \mathrm{~g} \mathrm{~cm}^{-3}, \mathrm{H}_{\mathrm{S}}=$ $0.7, \mathrm{Y}_{\mathrm{X} / \mathrm{S}}=60$, and the constants in mass transfer coefficient equation $\mathrm{a}_{0}=0.038$ and $\mathrm{a}_{1}=0.25$.

The authors would like to acknowledge Directorate General of Higher Educations of Indonesia for financial support of this work throug research grant of Hibah Bersaing 2015.

\section{References}

1. H.R. Amini, D.R. Reinhart, Waste Manage., 31, 2020-2026 (2011).

2. T. R. Yadvika, S. Santosh, Sreekrishnan, V. Kohli, Rana, Bioresour. Technol., 95, 1-10 (2004).

3. M. Syed, G. Soreanu, P. Falletta, M. Béland, Can. Biosyst. Eng. 48 (2006) 2.1-2.14.

4. S. Pipatmanomai, S. Kaewluan, T. Vitidsant, Appl. Energy, 86, 669-674 (2008).

5. C.C. Lien J.L. Lin, C.H. Ting, Water Scrubbing for, J. Agric. Chem. Environ. 3, 1-6 (2014).

6. H.B. Boumnijel, H. Amor, N. H. Chekir, C. R. Chim., 30, 1-8(2016).

7. M. Taheri, A. Mohebbi, H. Hashemipour, A.M. Rashidi, J. Nat. Gas Sci. Eng. 28 410-417 (2016)

8. M.R.A. Al Mamun, S. Torii, J. Clean Energy Technol., 3, 6, 428-432, (2015).

8. C. Rattanapan, P. Boonsawang, D. Kantachote, Bioresour. Technol., 100, 125-130 (2009).

9. Elias, A. Barona, A. Arreguy, J. Rios, I. Aranguiz, J. Penas, Process Biochem., 37, 813-820 (2002).

10. M.A. Deshusses, G. Hamer, and I.J. Dunn, Environ. Sci. Technol., 29. 1408-1458 (1995).

11. J.S. Devinny, M.A. Deshusses, and T.S. Webster, Boca Raton. 5-16 (1999). 
12. S. Craig, Microbiology: breaking down biofilm. Curr Biol;19:R132-4 (2002).

13. F.P. Chávez, F. Gordillo, C.A. Jerez, Biotechnol. Adv., 24: 309-20 (2006).

14. P. Edmonds, Microbiology an environmental Perspective, Collier Macmillan Publisher. LondonNew York (1978).

15. M. Hirai, M. Ohtake, and M. Shoda, J. Ferment. Bioeng. (1990)

16. R.A.S. Lestari, W.B. Sediawan and Sarto, $2^{\text {nd }}$ International Conference on Engineering and Technology for Sustainable Development, Yogyakarta, 13-14 September (2017).

17. G. Spigno, M. Zilli, C. Nicolella, Biochem. Eng. J. 19 (2004).

18. S. Majumder, G. Gangadhar, S. Raghuvanshi, S Gupta, Journal of Water Process Engineering, 6, 136-143 (2015).

19. M.B. Jaber, A. Couverta, A. Amranea, F. Rouxel, P. Cloireca, L.E. Dumontd, Biochem. Eng. J., 112, 153160 (2016).

20. V. Meena, L. Rajendran, S. Kumar, P.G.J. Rani, Egyptian journal of basic and applied sciences, 3, 94-105 (2016).

21. J.M. Santos, E.S. Lopes, N.C.R. Junior, L. Melo de Sa, N.J. Horand, Water Res., 43, 3355 - 3364 (2009).

22. S. Kim, and M.A. Deshusses, Chem. Eng. Sci., 63, $841-855$ (2008).

23. C. Yang, M.T. Suidan, X. Zhub, B.J. Kimc, G. Zeng, Water Res., 42,3641-3650 (2008).

24. A.A. Ramirez, S. Bénard, A.G. Fendler, J.P. Jones, M. Heitz, J. Biotechnol. 138, 88-95 (2008).

25. Visscher, A.D., Li, G.Q., 2008, Toluene removal biofilter modeling: Optimization and case Study, process safety and environment protection $86,277-$ 282.

26. G.K. Agarwal, A.K. Ghoshal, Bioresour. Technol., 99, 3765-3773 (2008).

27. R.A.S. Lestari, W.B. Sediawan, and Sarto, The $2^{\text {nd }}$ International Conference on Engineering and Technology for Sustainable Development (2017).

28. R.A.S. Lestari, W.B. Sediawan, S. Syamsiah, and Sarto, Eng. J., 4, 2370-2377 (2016). 